\title{
Recurrent Lung Large Cell Carcinoma
}

National Cancer Institute

\section{Source}

National Cancer Institute. Recurrent Lung Large Cell Carcinoma. NCI Thesaurus. Code C8753.

The reemergence of large cell lung carcinoma after a period of remission. 